\title{
MODEL DAN RANCANGAN EVALUASI PROGRAM BIMBINGAN DAN KONSELING
}

\author{
Siti Wahyuni Siregar \\ Fakultas Dakwah dan Ilmu Komunikasi IAIN Padangsidimpuan \\ (Email: sitiwahyunisiregar@yahoo.co.id)
}

\begin{abstract}
Evaluation is an attempt to obtain information on a regular, continuous, and comprehensive basis of the process and outcomes of the development of attitudes and behaviors, or the developmental tasks of the students through the program activities that have been implemented. The model of evaluation arises because of continuous explanation efforts derived from human development and desire to try to apply the principles of evaluation on a more abstract scope including in the fields of education, behavior and art. In this paper we will present some models that can be used in the evaluation of guidance and counseling programs, ie goal attainment evaluation model, formative and summative evaluation model, responsive evaluation model and CIPP evaluation model (Context, Inputs, Process and Product). Some things to consider in designing evaluation of guidance and counseling programs are: title of activities, reasons of implementation, general goals and specific objectives, evaluation questions, methodologies used and procedures and steps of evaluation activities. Keywords: Evaluation, Model, and Design.
\end{abstract}

\begin{abstract}
Abstrak
Evaluasi adalah suatu usaha untuk mendapatkan berbagai informasi secara berkala, berkesinambungan, dan menyeluruh tentang proses dan hasil dari perkembangan sikap dan perilaku, atau tugas-tugas perkembangan para siswa melalui program kegiatan yang telah dilaksanakan. Model evaluasi muncul karena adanya usaha eksplanasi secara kontinu yang diturunkan dari perkembangan dan keinginan manusia untuk berusaha menerapkan prinsip-prinsip evaluasi pada cakupan yang lebih abstrak termasuk pada bidang ilmu pendidikan, perilaku dan seni. Dalam makalah ini akan dipaparkan beberapa model-model yang dapat digunakan dalam evaluasi program bimbingan dan konseling, yaitu model evaluasi goal attainment, model evaluasi formative dan summative, model evaluasi responsive dan model evaluasi CIPP (Context, Inputs, Process dan Product). Beberapa hal yang harus diperhatikan dalam merancang evaluasi program bimbingan dan konseling yaitu: judul kegiatan, alasan dilaksanakannya, tujuan umum dan tujuan khusus, pertanyaan evaluasi, metodologi yang digunakan serta prosedur dan langkah-langkah kegiatan evaluasi.
\end{abstract}

Kata kunci : Evaluasi, Model, dan Rancangan. 


\section{A. Pendahuluan}

Evaluasi adalah suatu proses pengumpulan informasi (data) untuk mengetahui efektivitas (keterlaksanaan dan ketercapaian) kegiatan-kegiatan yang telah dilaksanakan dalam upaya mengambil keputusan. Pengertian lain evaluasi adalah suatu usaha untuk mendapatkan berbagai informasi secara berkala, berkesinambungan, dan menyeluruh tentang proses dan hasil dari perkembangan sikap dan perilaku, atau tugas-tugas perkembangan para siswa melalui program kegiatan yang telah dilaksanakan. ${ }^{1}$

Evaluasi atau penilaian merupakan bagian penting dalam pengelolaan atau manajemen pelaksanaan bimbingan dan konseling sesuai dengan perkembangan yang terjadi baik pada program sekolah secara keseluruhan, perkembangan sosial dan tantangan yang terjadi dalam pendidikan maka program layanan bimbingan dan konseling tidak boleh statis atau itu ke itu. Demikian pula dilihat dari perkembangan program itu sendiri, suatu program layanan bimbingan dan konseling perlu dikembangkan dan diperbaiki sehingga dapat dirancang dan direalisasikan sesuai dengan perkembangan kebutuhan peserta didik sebagai salah satu sasaran layanan. Sekalipun layanan evaluasi bukan merupakan layanan yang langsung kepada siswa, namun pelaksanaan evaluasi akan memberikan dampak terhadap peningkatan layanan yang dibutuhkan oleh siswa. Sehingga pada akhirnya siswa dapat merasakan dampak peningkatan atau perubahan yang sesuai dengan dinamika pada aspek yang dikembangkan dalam suatu program. ${ }^{2}$

Pada konteks pembelajaran, evaluasi pada umumnya berorientasi pada tujuan pendidikan yang didalamnya mencakup beberapa macam tujuan termasuk tujuan pendidikan nasional, tujuan institusi, tujuan instruksional umum dan tujuan instruksional khusus yang didalamnya mengandung penampilan (performance). Pada konteks yang lebih luas, evaluasi kurikulum maupun evaluasi sistem bervariasi sesuai dengan pilihan dari evaluator itu sendiri. Pada konteks yang lebih luas, misalnya evaluasi kurikulum atau sistem kelembagaan dikenal dengan

\footnotetext{
${ }^{1}$ Mamat Supriatna, Bimbingan dan Konseling Berbasis Kompetensi; Orientasi Dasar Pengembangan Profesi Konselor, (Jakarta: Rajawali Press, 2011), h.80.

2 Kementrian Pendidikan dan Kebudayaan Direktorat Jenderal Pendidikan Menengah Direktorat Pembinaan PTK Dikmen, Materi Bimbingan Teknis Pengembangan Karir Guru BK Dikmen, (2012), h.176.
} 
adanya macam-macam model evaluasi yang digunakan untuk memudahkan pemahaman tentang evaluasi.

Model secara definisi diartikan sebagai a likeness that aid on in understanding a structure process used by scientist, when the phenomena studied would otherwise be underscribable. ${ }^{3}$ Atau sesuatu yang membantu dalam pemahaman struktur atau proses yang digunakan oleh ahli, ketika fenomena dipelajari untuk dapat diterangkan. Di samping itu, Sukardi memberikan batasan tentang model atau paradigma yaitu struktur sejenis berfungsi sebagai penyederhanaan konsep yang digunakan untuk mempelajari secara intensif tentang model, seorang evaluator dapat lebih mudah memahami dan kemudian evaluasi dalam konteks yang lebih luas. ${ }^{4}$

Model evaluasi muncul karena adanya usaha eksplanasi secara kontinu yang diturunkan dari perkembangan dan keinginan manusia untuk berusaha menerapkan prinsip-prinsip evaluasi pada cakupan yang lebih abstrak termasuk pada bidang ilmu pendidikan, perilaku dan seni. Dalam makalah ini akan dipaparkan beberapa model-model yang dapat digunakan dalam evaluasi program bimbingan dan konseling, yaitu model evaluasi goal attainment, model evaluasi formative dan summative, model evaluasi responsive dan model evaluasi CIPP (Context, Inputs, Process dan Product).

\section{B. Pembahasan}

\section{Model Evaluasi Program Bimbingan dan Konseling}

\section{a. Model Evaluasi Goal Attainment}

Tyler adalah seorang yang dianggap bapak evaluasi, karena pada tahun 1950 telah memberikan sumbangannya dalam memberikan definisi pada evaluasi. Tyler dalam Brinkerhoff memandang evaluasi sebagai bagian proses penentuan arah mengaktualisasikan tujuan pendidikan. Tyler menganggap evaluasi merupakan proses membandingkan antara tujuan yang ditetapkan dengan tujuan yang dapat dicapai. Definisi Tyler ini memiliki penekanan pada apa yang telah dicapai melalui program. Definisi yang dikemukakan oleh Tyler ini kemudian diikuti oleh beberapa ahli evaluasi setelahnya, seperti Met Fesel, Michael, dan

${ }^{3}$ Sukardi, Evaluasi Pendidikan; Prinsip \& Operasional, (Jakarta: Bumi Aksara, 2008), hlm. 55. 
juga Provus, yang memberikan penekanan evaluasi pada pencapaian hasil dari program. $^{5}$

Menurut Tyler pengertian evaluasi perlu ditekankan pada pemerolehan gambaran mengenai efektivitas sistem pendidikan yang mempengaruhi pencapaian tujuan pendidikan/ pembelajaran. Penekanan evaluasi pada aspek hasil ini didasarkan pada pemahaman bahwa tujuan pendidikan/ pembelajaran adalah adanya perubahan tingkah laku yang diinginkan pada peserta didik. Untuk itu, maka evaluasi diarahkan untuk memeriksa sejauh mana perubahan-perubahan tingkah laku yang diinginkan itu telah terjadi pada peserta didik. Dengan diperolehnya informasi mengenai sejauh mana tujuan-tujuan dicapai, dapat diambil keputusan tentang tindakan yang perlu diambil sehubungan dengan perbaikan sistem pendidikan dan peserta didik yang bersangkutan. ${ }^{6}$

Evaluasi harus dilaksanakan secara berkesinambungan dan terus menerus sesuai dengan tujuan pembelajaran yang akan dicapai secara berkelanjutan. Perubahan tingkah laku sebagai hasil tidak hanya terbatas pada segi pengetahuan (kognitif) saja, melainkan juga mencakup dimensi keterampilan dan nilai atau sikap. Bervariasinya tujuan pendidikan tersebut memberikan implikasi pada penggunaan alat ukur/ instrumen evaluasi. Evaluasi tidak lagi hanya menggunakan tes tertulis, akan tetapi juga tes perbuatan, lembar pengamatan, serta inventori.

\section{1) Langkah-langkah Evaluasi}

Model evaluasi berbasis tujuan telah dikembangkan dan digunakan selama delapan tahun pada akhir 1930. Proses ini membawa Tyler memahami evaluasi sebagai proses menentukan seberapa besar tujuan sebuah program dapat dicapai. Berdasarkan pemikiran itulah, maka Tyler mengembangkan langkah-langkah yang digunakan dalam melakukan sebuah evaluasi. Langkah-langkah tersebut meliputi: ${ }^{7}$

a) Menentukan tujuan seluas-luasnya atau sasaran-sasaran.

b) Mengklasifikasikan tujuan-tujuan atau sasaran-sasaran.

\footnotetext{
${ }^{5}$ Aip Badrujaman, Teori dan Aplikasi Evaluasi Program Bimbingan Konseling, (Jakarta: Indeks, 2011), hlm. 40.

${ }_{7}^{6}$ Ibid.

${ }^{7}$ lbid.
} 
c) Menegaskan sasaran dalam bentuk perilaku.

d) Menemukan situasi-situasi dalam pencapaian tujuan yang dapat dilihat.

e) Mengembangkan atau memilih teknik pengukuran.

f) Mengumpulkan hasil data.

g) Membandingkan hasil data dengan perilaku berdasarkan tujuan

Goodlad dalam Sanders (2004) berpendapat bahwa Tyler mempermudah evaluasi karena adanya tujuan umum untuk menentukan tujuan lebih baik daripada penentuan tujuan khusus (perilaku) yang tidak tepat. Meskipun demikian, tujuan yang luas untuk kegiatan apapun pada akhirnya menuntut definisi operasional. Adanya definisi operasional membuat rencana pengukuran dan pengaturan dapat dipilih. Melalui penentuan tujuan umum dan khusus, Tyler percaya bahwa penyedia layanan dibutuhkan untuk merundingkan kepentingan dan arti tujuan umum layanan mereka.

Satu publikasi yang menyatakan pemikiran mengenai tujuan pendidikan yaitu Handbook Educational Variables. Pedoman tersebut membagi perkembangan siswa tingkat dasar dan siswa tingkat dua dalam tujuh kategori, meliputi: kecerdasan, emosi, fisik dan rekreasi, estetis dan kebudayaan, moral, kejujuran serta sosial.

Satu dari tiap kategori ini telah diuraikan dalam bagian yang begitu luas untuk dikembangkan. Seperti sumber mencontohkan tingkatan pada pendekatan evaluasi yang telah dikembangkan oleh Tyler. Goodlad menekankan bahwa evaluasi pendidikan di Amerika tidak bisa membuat banyak kemajuan sampai tujuan ini dibahas, diterima, diterapkan secara operasional, dan diawasi. Tyler menekankan pentingnya memeriksa sebagai dasar untuk mengevaluasi kegiatan. Pemeriksaan tujuan yang menggunakan tiga sumber : Filosofi (sifat pengetahuan), sosial (sifat masyarakat), dan pedagogis (sifat dari pelajar dan proses pembelajaran).

Pendekatan berorientasi tujuan telah mendominasi pikiran dan perkembangan dari evaluasi sejak tahun 1930 di USA dan di wilayah lain. Bloom dan Karathwohl memengaruhi perbaikan pendekatan evaluasi berorientasi tujuan dengan penelitian mereka tentang taksonomi tujuan pendidikan yang memiliki tiga ranah, meliputi: ranah kognitif, ranah afektif dan ranah konatif. Dengan 
perkembangan taksonomi tujuan ini, pendidik memiliki peralatan yang kuat untuk membantu mereka dalam penggunaan pendekatan Tyler dalam evaluasi.

\section{2) Kelebihan dan Kekurangan Model Evaluasi Goal Attainment}

Model evaluasi goal attainment merupakan model yang sederhana. Penekanan evaluasi hanya pada aspek hasil saja memuat evaluasi lebih mudah dipahami, diikuti dan diimplementasikan. Model evaluasi ini sudah disimulasikan selama bertahun-tahun sehingga menghasilkan tindakan dan instrumen yang sudah diperhalus. Literatur evaluasi berorientasi tujuan banyak, serta diisi dengan ide kreatif untuk mengaplikasikan pendekatan ini. ${ }^{8}$

Perkembangan model evaluasi berbasis tujuan dalam waktu yang lama membuat cara-cara melakukan pengukuran menjadi bervariasi. Tyler mencoba menggunakan ukuran-ukuran lain dari suatu capaian yang tidak sama dengan ukuran-ukuran yang dipergunakan sebelumnya. Kemajuan ini, ditambahkan lagi dengan adanya pengembangan berbagai instrumen, baik individual maupun kelompok yang dapat digunakan dalam evaluasi.

Meskipun memiliki kelebihan, akan tetapi model evaluasi goal attainment ini juga memiliki kekurangan. Beberapa kekurangan tersebut meliputi: ${ }^{9}$

a) Mengabaikan aspek perencanaan dan proses pada proses pembelajaran.

b) Banyak kekurangan standar penilaian yang penting untuk diobservasi.

c) Ketidaksesuaian antara tingkat tujuan dan pelaksanaannya.

d) Pengabaian nilai tujuan pendekatan evaluasi itu sendiri.

e) Mengabaikan alternatif-alternatif penting yang harus dipertimbangkan dalam perencanaan program.

f) Melalaikan konteks yang memiliki wewenang evaluasi.

g) Mengabaikan hasil penting lainnya yang ditutupi oleh tujuan (hasil yang sengaja didapatkan dari kegiatan).

h) Mengabaikan fakta-fakta dari nilai program yang tidak dapat digambarkan dengan tujuan itu sendiri.

\section{b. Model Evaluasi Formative dan Summative}

Model evaluasi formative dan summative dikemukakan oleh Michael Scriven $^{10}$ yang memberikan definisi berbeda mengenai evaluasi. Scriven mendefinisikan evaluasi sebagai proses mengumpulkan dan mengkombinasikan

\footnotetext{
8 Ibid, hlm. 42.

9 lbid, hlm. 43.

${ }^{10}$ Wirawan, Evaluasi; Teori, model, Standar, Aplikasi dan Profesi, (Jakarta: Rajawali Press, 2011), h. 85.
} 
data performance dengan seperangkat tujuan yang telah ditetapkan. Definisi Scriven ini, tidak hanya memberikan tekanan pada pencapaian hasil, akan tetapi juga memberikan perhatian pada aspek proses.

\section{1) Evaluasi Formatif}

Sriven mendefinisikan evaluasi formatif sebagai suatu evaluasi yang biasanya dilakukan ketika suatu produk atau program tertentu sedang dikembangkan dan biasanya dilakukan lebih dari sekali dengan tujuan untuk melakukan perbaikan. Sementara Weston, McAlpine dan Bordonaro (1995) menjelaskan bahwa tujuan evaluasi formatif adalah untuk memastikan tujuan yang diharapkan dapat tercapai dan untuk melakukan perbaikan suatu produk atau program. Hal ini senada dengan apa yang disampaikan oleh Werthen dan Sanders (1997) bahwa evaluasi formatif dilakukan untuk memberikan informasi evaluatif yang bermanfaat untuk memperbaiki program. ${ }^{11}$

Fokus evaluasi berkisar pada kebutuhan yang dirumuskan oleh karyawan atau orang-orang program. Evaluator sering merupakan bagian dan kerjasama dengan orang-orang program. Strategi pengumpulan informasi mungkin juga dipakai, tetapi penekanan pada usaha memberikan informasi yang berguna secepatnya bagi perbaikan program. ${ }^{12}$

Dalam konteks bimbingan dan konseling, evaluasi formatif dapat didefinisikan sebagai suatu proses pengumpulan data untuk menentukan keberhasilan atau menilai tentang kelebihan dan kelemahan suatu program ketika program tersebut masih dalam tahap pengembangan (proses kegiatan sedang berjalan), kekuatan dan kelemahan yang terindentifikasi melalui evaluasi forrmatif kemudian digunakan sebagai bahan acuan untuk melakukan perbaikan (revisi). Tujuan evaluasi formatif adalah untuk merevisi program layanan yang sedang dikembangkan dengan cara mengumpulkan data dari berbagai sumber dengan menggunakan berbagai metode dan alat pengumpul data tertentu. ${ }^{13}$ h. 43 .

${ }^{11}$ Aip Badrujaman, Teori dan Aplikasi Evaluasi Program Bimbingan Konseling...,

12 S. Eko Puto Widoyoko, Evaluasi Program Pembelajaran; Panduan Praktis Bagi Pendidik dan Calon Pendidik, (Yogyakarta: Pustaka Pelajar, 2009), h. 188. h. 44 .

${ }^{13}$ Aip Badrujaman, Teori dan Aplikasi Evaluasi Program Bimbingan Konseling...., 
Evaluasi formatif dapat menanggapi program dalam konteks yang dinamis, dan berusaha memperbaiki keadaan kerumitan yang merupakan bagian yang tidak dapat dihindarkan dari berbagai bentuk program dalam lingkungan kebijakan yang berubah-ubah. Kesesuaian antara perencanaan dan pelaksanaan program baik pada konteks organisasi, personel, struktur dan prosedur menjadi fokus evaluasi ini. Beberapa ketidakcocokan antara petunjuk dan pelaksanaan dapat dijadikan dasar untuk menganalisis kekuatan dan kelemahan, menemukan halangan, rintangan serta peluang yang ada untuk menimbulkan pemahaman tentang bagaimana program dapat diimplementasikan secara lebih baik.

Evaluasi dilakukan dengan mengumpulkan dan menganalisis data dari seluruh pelaksanaan program dan timbal balik yang tepat dari evaluasi. Hal ini dimaksudkan agar terdapat informasi yang akurat bagi pelaku program dalam rangka pengambilan keputusan dan tindak lanjut. Baker (1978) mengatakan ada dua faktor yang mempengaruhi kegunaan evaluasi formatif, yaitu kontrol dan waktu. Bila sasaran perbaikan akan dijalankan, maka evaluasi formatif diperlukan sebagai kontrol. Informasi yang diberikan menjadi jaminan apakah kelemahan dapat diperbaiki. Apabila informasi mengenai kelemahan tersebut terlambat sampai kepada pengambil keputusan, maka evaluasi akan bersifat sia-sia.

\section{2) Teknik Evaluasi Formatif}

Evaluasi formatif terdiri dari beragam bentuk. Menurut Tessmer (1996) evaluasi formatif dapat dilakukan sebagai berikut:

a. Review ahli (expert review), yakni evaluasi dimana ahli mengkaji ulang program layanan dengan atau tanpa kehadiran evaluator. Ahli ini bisa ahli materi, ahli teknis, pearncang atau instruktur.

b. Evaluasi orang per orang (one to one evaluation), yakni wawancara yang dilakukan secara perorangan oleh evaluator terhadap beberapa siswa dimana secara satu per satu siswa diminta untuk memberikan komentarnya.

c. Evaluasi kelompok kecil (small group), yakni evaluasi dimana evaluator mengujicobakan suatu program layanan pada suatu kelompok siswa dan mencatat performance dan komentar-komentarnya.

d. Uji lapangan (field test), yakni evaluasi dimana evaluator mengobservasi program layanan yang diujicobakan kepada sekelompok siswa tertentu dalam suatu situasi nyata. ${ }^{14}$

\footnotetext{
${ }^{14}$ Ibid, h. 44-45.
} 


\section{3) Evaluasi Sumatif}

Evaluasi sumatif dilaksanakan untuk menilai manfaat suatu program sehingga dari hasil evaluasi akan dapat ditentukan suatu program tertentu akan diteruskan atau dihentikan. Pada evaluasi sumatif difokuskan pada variabelvariabel yang dianggap penting bagi sponsor program maupun pihak pembuat keputusan. Evaluator luar dan tim review sering dipakai karena evaluator internal dapat mempunyai kepentingan yang berbeda. Waktu pelaksanaan evaluasi sumatif terletak pada akhir implementasi program. Strategi pengumpulan informasi akan memaksimalkan validitas eksternal dan internal yang mungkin dikumpulkan dalam waktu yang cukup lama. ${ }^{15}$

Beberapa keuntungan dari evaluasi sumatif meliputi: ${ }^{16}$

a) Mereka bisa, jika dirancang dengan tepat, menyediakan bukti untuk sebuah hubungan sebab-akibat.

b) Menilai efek jangka panjang.

c) Menyediakan data mengenai dampak program.

\section{c. Model Evaluasi Responsif}

Evaluasi menurut Stake adalah usaha mendeskripsikan program-program dan memberikan judgment kepadanya. Evaluasi responsif adalah sebuah pendekatan untuk dievaluasi pendidikan dan program lainnya. Dibandingkan dengan pendekatan lainnya, evaluasi responsif lebih berorientasi pada aktivitas, keunikan dan keragaman sosial dari program. Keistimewaan utama dari pendekatan ini adalah kemampuan reaksi terhadap isu kunci atau masalah yang dikenal masyarakat di lapangan. Tujuan evaluasi dirancang secara perlahan dan terus berkembang selama proses pengumpulan data berlangsung. ${ }^{17}$

Patton dalam Isaac dan William (1984) menegaskan bahwa dalam mengevaluasi suatu program, metode kualitatif dapat sangat mempertinggi pemanfaatan temuan evaluasi. Hal ini disebabkan karena data evalausi kualitatif betul-betul dipertimbangkan secara personal, artinya evaluator memahami

${ }^{15}$ S. Eko Puto Widoyoko, Evaluasi Program Pembelajaran; Panduan Praktis..., h. 189.

${ }^{16}$ Aip Badrujaman, Teori dan Aplikasi Evaluasi Program Bimbingan Konseling.., h. 48 .

17 Ibid, h. 49. 
masalah dari sudut pandang audience. Pemahaman evaluator ini didapat karena evaluator menggunakan prosedur pengamatan serta wawancara secara mendalam, yang membuat berbagai informasi dapat digali secara mendalam dan natural dengan tetap memberikan sikap hormat kepada responden dengan menjadikan ide dan pendapat mereka yang kemudian dinyatakan dalam istilah.

Evaluasi responsif ditandai oleh ciri-ciri penelitian kualitatif naturalistik. Evaluasi responsif percaya bahwa evaluasi yang berarti yaitu mencari pengertian isu dari berbagai sudut pandang semua orang yang terlibat, yang berminat, dan yang berkepentingan dalam program. Data lebih banyak dikumpulkan menggunakan teknik wawancara dan observasi daripada tes dan angket. Keberadaan data yang kualitatif ini membuat analisis dan interpretasi data bersifat impresionistik. Bentuk laporan evaluasi adalah studi kasus atau gambaran yang bersifat deskriptif. Fokus utama evaluasi responsif adalah menunjukkan perhatian dan isu peserta/ stakeholder.

Stake (1972) mencatat bahwa ia tidaklah mengusulkan suatu pendekatan baru ke evaluasi, “evaluasi responsif memberikan fokus pada orang-orang yang terlibat dalam evaluasi, dilakukan pada setting yang alamiah, dimana evaluator mengamati dan bereaksi. Suatu evaluasi bidang pendidikan adalah evaluasi responsif jika memiliki orientasi lebih secara langsung ke aktivitas program dibanding ke tujuan program; beraksi terhadap kebutuhan. Pendengar untuk informasi dan mempertimbangkan perspektif nilai dalam melaporkan kegagalan dan kesuksesan program. Pendekatan responsif mencoba untuk bereaksi terhadap isu penting dalam program.

Tujuan, kerangka dan fokus (dari dan tentang) evaluasi responsif muncul dari interaksi dengan unsur, dan pengamatan terhadap interaksi. Kondisi ini mengakibatkan evaluasi berkembang secara progresif. Artinya isu dalam evaluasi responsif berkembang sepanjang evaluasi dilakukan, sepanjang data-data dikumpulkan.

Kunci dalam evaluasi responsif adalah evaluator harus mau mendengarkan audience-nya. Penilai responsif tentu saja mengerjakan banyak berbagai hal. Ia membuat suatu rencana pengamatan dan negosiasi. Stake menggunakan "jam" yang ditunjukkan di (dalam) figure sebagai nemonic (ingatan). Menurut Stake, 
walaupun cara terbaik melakukan evaluasi adalah mulai dari jam duabelas dan berproses searah jarum jam, akan tetapi Stake melihat semua peristiwa dapat mengikuti peristiwa lain, dan pada titik (jam) manapun penilai boleh pindah atau bergerak berlawanan arah jarum jam atau close-clockwise. Berdasarkan penjelasan Stake, tahapan kegiatan evaluasi dalam model responsif terlihat fleksibel.

\section{1) Model Judgment dari Stake}

Evaluasi menurut Stake ialah usaha mendeskripsikan dan memberikan judgment pada program-program. Model evaluasi ini bukan hanya menekankan pada keputusan yang dibuat sepanjang evaluasi, tetapi juga menambahkan dimensi lain yaitu deskripsi. Model ini berpandangan bahwa kegiatan penilaian tidak hanya berakhir pada suatu deskripsi tentang keadaan, peristiwa, kejadian atau objek melainkan harus sampai pada judgment mengenai baik-buruknya, efektif tidaknya proses dan akhinya pada program. Stake mengatakan bahwa evaluasi tidak sempurna jika tidak memberikan judgment. Dalam memberikan judgment dapat digunakan standar atau kriteria absolut (mutlak) atau relatif.

Stake menawarkan tiga fase dalam evaluasi yakni: ${ }^{18}$

a) Antecedents dimaksudkan untuk menilai sumber/modal/input, seperti tenaga keuangan, karakteristik siswa dan tujuan yang ingin dicapai.

b) Tahap transaksi dimaksudkan untuk menilai rencana kegiatan dan proses pelaksanaannya, termasuk ke dalamnya urutan kegiatan, penjadwalan waktu, bentuk interaksi dan seterusnya.

c) Outcomes dimaksudkan untuk menilai efek dari program setelah selesai dilaksanakan.

\section{2) Kelebihan dan kekurangan}

Kelebihan pendekatan responsif adalah kepekaannya terhadap berbagai titik pandangan, dan kemampuannya mengakomodasi pendapat yang ambigu dan tidak fokus. Demikian juga evaluasi responsif dapat mendorong proses perumusan masalah dengan cara menyediakan informasi yang dapat membantu kita memahami isu secara lebih baik.

Keterbatasan pendekatan responsif adalah keengganannya membuat prioritas atau penyederhanaan informasi untuk pemegang keputusan dan

\footnotetext{
${ }^{18}$ Ibid, h. 51.
} 
kenyataan yang praktis tidak mungkin menampung semua sudut pandang dari berbagai kelompok. Evaluator dalam pendekatan ini, harus dapat menempatkan diri di posisi orang lain. Dia tidak boleh membuat kesimpulan sendiri, tetapi lebih sebagai pihak yang memeriksa dan mengecek kembali kepastian pada sumber data primer. evaluator bertindak sebagai konselor, menolong peserta program, memperjelas pengertian mereka tentang programnya sendiri. ${ }^{19}$

\section{d. Model Evaluasi CIPP}

Model evaluasi ini merupakan model yang paling banyak dikenal dan diterapkan oleh beberapa evaluator. Model context input process product (CIPP) merupakan hasil kerja para tim peneliti, yang bergabung dalam suatu organisasi komite Phi Delta Kappa USA, yang ketika itu diketuai oleh Daniel StuffleBeam. ${ }^{20}$ Stufflebeam merupakan ahli evaluasi yang mengusulkan evaluasi melalui pendekatan yang berorientasi kepada pengambilan keputusan (a decision oriented evaluation approach structured). Sufflebeam berpendapat bahwa evaluasi seharusnya memiliki tujuan untuk memperbaiki (to improve) bukan untuk membuktikan (to prove).

Dengan demikian evaluasi seharusnya dapat membuat suatu perbaikan, meningkatkan akuntabilitas, serta pemahaman yang lebih dalam mengenai fenomena. Menurut Sufflebeam, evaluasi seharusnya dapat memberikan gambaran yang menyeluruh terhadap program. Lebih daripada itu, menurutnya, penelaahan menyeluruh terhadap program harus dilakukan melalui sebuah cara yang sistematis. Sufflebeam melihat evaluasi sebagai sebuah tahapan yang sistematis dan menyeluruh. Pada akhirnya, ia melihat terdapat empat komponen evaluasi yang juga merupakan tahapan dalam evaluasi. Keempat komponen tersebut adalah context, input, process, serta product. ${ }^{21}$

\section{1) Evaluasi Konteks (context evaluation)}

Evaluasi konteks merupakan penggambaran dan spefikasi tentang lingkungan program, kebutuhan yang belum terpenuhi, karakteristik populasi dan sampel dari individu yang dilayani dan tujuan program. Evaluasi konteks membantu merencanakan keputusan, menentukan kebutuhan yang akan dicapai

\footnotetext{
${ }^{19}$ Ibid, h. 52-53.

${ }^{20}$ M. Sukardi, Evaluasi Pendidikan; Prinsif \& Operasional.... h. 62.

${ }^{21}$ Aip Badrujaman, Teori Dan Aplikasi Evaluasi....hlm, 54.
} 
oleh program dan merumuskan tujuan program. Evaluasi konteks menurut Suharsimi (2008:46) dilakukan untuk menjawab pertanyaan: a). kebutuhan apa yang belum dipenuhi oleh kegiatan program, b). tujuan pengembangan manakah yang berhubungan dengan pemenuhan kebutuhan, c). tujuan manakah yang paling mudah dicapai. $^{22}$

\section{2) Evaluasi Input (input evaluation)}

Evaluasi input membantu mengatur keputusan, menentukan sumbersumber yang ada, alternatif apa yang diambil, apa rencana dan strategi untuk mencapai tujuan, bagaimana prosedur kerja untuk mencapainya. Komponen evaluasi input meliputi: a). sumber daya manusia, b). sarana dan peralatan pendukung, c). dana/ anggaran, dan d). berbagai prosedur dan aturan yang diperlukan. ${ }^{23}$ Input dalam bimbingan dan konseling dapat berupa jumlah sumber daya manusia dalam divisi bimbingan dan konseling, dukungan keuangan, ruangan, peralatan (komputer, software serta media bimbingan).

Evaluasi ini dapat dilakukan dengan menggunakan metode menginventarisasi dan menganalisis sumber-sumber yang tersedia, baik guru bimbingan dan konseling, ataupun material, strategi solusi, relevansi desain prosedur, kepraktisan dan biaya, kemudian dibandingkan dengan kriteria yang ditetapkan berdasarkan telaah literatur atau dengan mengunjungi program yang telah berhasil atau berdasarkan ahli.

\section{3) Evaluasi Proses (process evaluation)}

Evaluasi proses merupakan evaluasi yang dilakukan untuk melihat apakah pelaksanaan program sesuai dengan strategi yang telah direncanakan. Evaluasi proses bertujuan untuk mengidentfikasikan atau memprediksi dalam proses pelaksanaan, seperti cacat dalam desain prosedur atau implementasinya. Evaluasi proses juga bertujuan untuk menyediakan informasi sebagai dasar memperbaiki program, serta untuk mencatat, dan menilai prosedur kegiatan dan peristiwa. ${ }^{24}$

Evalausi proses ini dapat dilakukan dengan memonitor kegiatan, berinteraksi terus-menerus, serta dengan mengobservasi kegiatan dan staf. Hal ini 182.

${ }^{22}$ S. Eko Puto Widoyoko, Evaluasi Program Pembelajaran; Panduan Praktis..., hl

23 Ibid.

${ }^{24}$ Aip Badrujaman, Teori Dan Aplikasi Evaluasi....h, 55. 
dapat melibatkan pengukuran pre-test dan post-test terhadap pengetahuan dan keterampilan, mengobservasi perilaku tertentu pada siswa, self-report mengenai perbaikan tingkah laku, penilaian performance rutin (tingkat, tes terstandar, portopolio), self study yang terus menerus, studi kasus individual, kehadiran dan data kedisiplinan, kesesuaian antara program dengan pelaksanaan, keterlaksanaan program, pengukuran sosiometri, serta hambatan-hambatan yang ditemui.

\section{4) Evaluasi Produk (product evaluation)}

Evaluasi produk adalah evaluasi yang berujuan untuk mengukur, menginterpretasikan, dan menilai pencapaian program. Feedback atas pencapaian/ prestasi ini penting selama pelaksanaan program dan sebagai sebuah kesimpulan. Evaluasi produk juga bertujuan mengumpulkan deskripsi dan penilaian terhadap luaran (outcome) dan menghubungkan itu semua dengan objektif, konteks, input, dan informasi proses, serta untuk menginterprestasikan kelayakan dan keberhargaan program.

Farida Yusuf Tayibnapis evaluasi produk untuk membantu membuat keputusan selanjutnya, baik mengenai hasil yang telah dicapai maupun apa yang dilakukan setelah program itu berjalan. ${ }^{25}$ Dengan demikian evaluasi produk merupakan penilaian yang dilakukan untuk mengukur keberhasilan dalam pencapaian tujuan yang telah ditetapkan. Data yang dihasilkan akan sangat menentukan apakah program diteruskan, dimodifikasi atau dihentikan.

Apabila ditinjau berdasarkan tujuan, model CIPP di atas dapat dikelompokkan menjadi dua bagian, meliputi tujuan (intention) dan yang telah terjadi (actual). Keempat komponen evaluasi CIPP bukanlah komponen yang berdiri sendiri-sendiri akan tetapi komponen yang saling berinteraksi secara dinamis. $^{26}$

\footnotetext{
${ }^{25}$ S. Eko Puto Widoyoko, Evaluasi Program Pembelajaran; Panduan Praktis..., h.
} 183.

\footnotetext{
${ }^{26}$ Aip Badrujaman, Teori Dan Aplikasi Evaluasi....h, 56-57.
} 


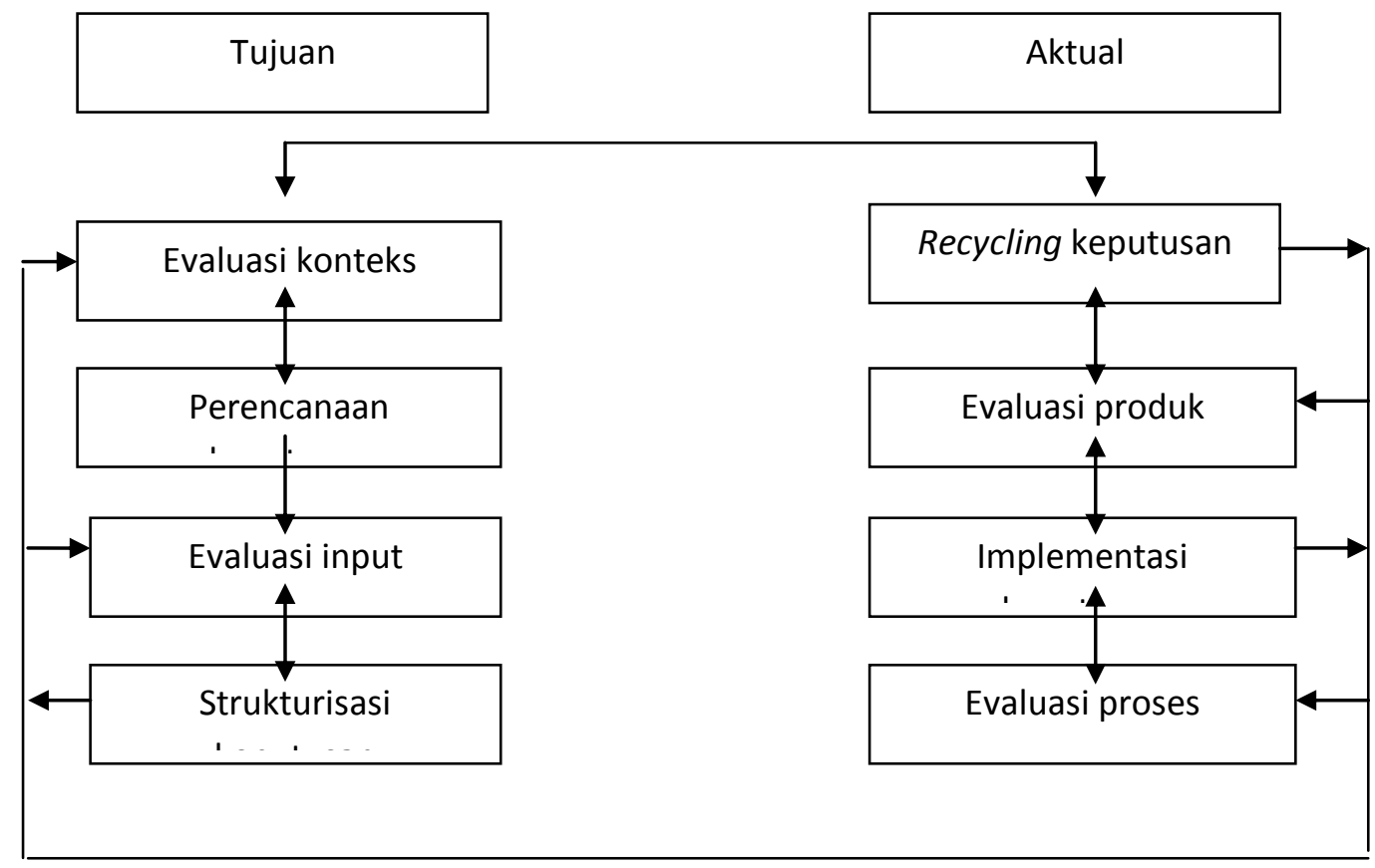

Berdasarkan diagram di atas, maka keempat komponen dalam model evaluasi CIPP dapat kita kelompokkan berdasarkan pelaksanaan program, dan penekanan masing-masing komponen tersebut. Pada diagram di atas dapat terlihat garis putus-putus vertikal yang membagi diagram menjadi dua bagian. Bagian sebelah kiri merupakan kelompok komponen CIPP yang termasuk dalam kelompok tujuan, artinya evaluasi konteks dan evaluasi input merupkan evaluasi yang dilakukan dalam rangka mengevaluasi bagian program yang masih bersifat perencanaan bukan pelaksanaan. Sedangkan bagian sebelah kanan, yaitu komponen evaluasi proses dan produk merupakan evaluasi yang dilakukan dalam rangka mengevaluasi bagian dari program yang sedang atau sudah dilaksanakan.

Garis putus-putus horizontal yang membagi diagram menjadi dua bagian menunjukkan bahwa keempat komponen model evaluasi CIPP dapat dikelompokkan pada dua bagian. Bagian pertama adalah bagian atas, dimana evaluasi konteks dan evaluasi produk merupakan evaluasi yang memiliki penekanannya pada hasil, sedangkan bagian bawah, dimana terdapat evaluasi input dan evaluasi proses menunjukkan bahwa kedua evaluasi tersebut memberikan fokusnya pada proses.

Berdasarkan alur yang ada pada diagram di atas, dapat dipahami bahwa evaluasi konteks merupakan evaluasi yang dilakukan untuk merencanakan 
keputusan melalui penelaahan kebutuhan untuk menetapkan tujuan. Setelah tujuan ditetapkan, maka untuk menstrukturisasikan keputusan dalam arti agar tujuan dapat tercapai maka diperlukan strategi. Menentukan strategi yang tepat dilakukan melalui evaluasi input. Strategi yang dirancang kemudian diterapakan dalam pelaksanaan untuk mencapai tujuan. Hal inilah yang membuat dalam diagram terdapat keterangan bahwa evaluasi konteks dan evaluasi produk dilakukan secara simultan. Evaluasi proses untuk melihat implementasi dari strategi yang dipilih, sedangkan evaluasi produk untuk melihat apakah tujuan telah tercapai. Evaluasi produk ini kemudian menjadi dasar untuk menentukan keputusan mengenai program.

\section{Rancangan Evaluasi Program}

Dalam setiap kegiatan penting dan ilmiah sebaiknya memang ada rancangan. Pada bagian ini akan membicarakan rancangan evaluasi program dengan batasan pengertian sebagai sebuah rencana kerja yang dibuat secara rinci dan dijadikan pedoman kerja oleh pelaksana evaluasi. Jika diibaratkan dengan model evaluasi, rancangan evaluasi dibuat berdasarkan model yang sudah dipilih. Oleh karena telah dibuktikan bahwa model evaluasi dapat diterapkan untuk semua jenis program maka rancangan evaluasi tersebut mengikuti program yang akan dievaluasi dengan model yang sudah ditentukan.

Secara umum proposal, terdiri dari dua bagian besar, yaitu bagian pendahuluan dan bagian metodologi. Pendahuluan menjelaskan semua hal termasuk penjelasan tentang program dan alasan evaluasi diadakan, sedangkan dalam rancangan hal-hal yang tidak menyangkut langkah tadi tidak dituliskan. Beberapa hal hanya dikemukakan secara singkat kecuali prosedur kerja yang menunjukkan langkah-langkah kegiatan. ${ }^{27}$

Berdasarkan uraian di atas dapat dijelaskan hal-hal yang dicantumkan dalam sebuah rancangan evaluasi, yaitu:

a. Judul kegiatan

Menyebutkan isi pokok kegiatan evaluasi yang mencantumkan nama kegiatan, program apa yang dievaluasi (atau bagian dari program), dan dapat juga

${ }^{27}$ Suharsimi Arikunto, Cepi Safruddin AJ, Evaluasi Program Pembelajaran, (Jakarta: Bumi Aksara, 2007), h. 42. 
mencantumkan model yang digunakan serta menyebutkan unit dan lokasi program.

b. Alasan dilaksanakannya

Menjelaskan adanya kebijakan tentang program yang menjadi objek sasaran, perkiraan adanya hambatan tentang pelaksanaan atau alasan mengapa dilaksanakan evaluasi.

c. Tujuan

Ada dua tujuan, umum dan khusus. Dalam tujuan khusus disebutkan secara rinci target yang harus dicapai dari evaluasi. Dalam hitungan, banyaknya butir tujuan tidak dibatasi tetapi menunjukkan batasan sekurang-kurangnya tiga kalimat, dan sebaiknya tidak lebih dari lima kalimat.

d. Pertanyaan evaluasi

Merumuskan beberapa pertanyaan yang akan dicari jawabannya melalui kegiatan evaluasi.

e. Metodologi yang digunakan

Menjelaskan tentang objek sasaran evaluasi yang dihasilkan dari identifikasi komponen program dan indikator, sumber data, merode yang digunakan, instrumen yang digunakan sebagai pelengkap metode pengumpul data.

f. Prosedur kerja dan langkah-langkah kegiatan

Membicarakan hal-hal yang terkait dengan proses yang akan dilalui oleh petugas evaluasi program. Dalam judul subbagian point $\mathrm{f}$ ini terdapat dua hal yang perlu dipahami sendiri-sendiri, yaitu (a) prosedur kerja dan (b) langkah-langkah kerja. Langkah-langkah kegiatan, dari arti katanya, sudah dapat diketahui artinya, yaitu langkah demi langkah semua kegiatan, sejak proses pemahaman terhadap program, menyusun instrumen dan mengujicobakan, mengumpulkan data, analisa data dan menyusun laporan. Agar pentahapan langkah dapat diketahui dengan jelas oleh para petugas evaluasi dan pemberi tugas, uraian tentang langkah ini seyogianya dilengkapi dengan paln of operation (biasa dikenal dengan singkatannya, yaitu plan-op), diterjemahkan menjadi "rencana operasi kegiatan" atau rencana kegiatan secara operasional. Dalam tampilan rencana operasi ini tercantum langkah-langkah kegiatan yang ditunjukkan langsung oleh jangka waktu dan saatnya. Tampilan penggalan waktu tidak ditentukan secara pasti, 
dipertimbangkan dengan durasi waktu evaluasi, namun yang umum adalah penggalan mingguan. Untuk lebih jelas, perhatikan contoh plan-op berikut ini.

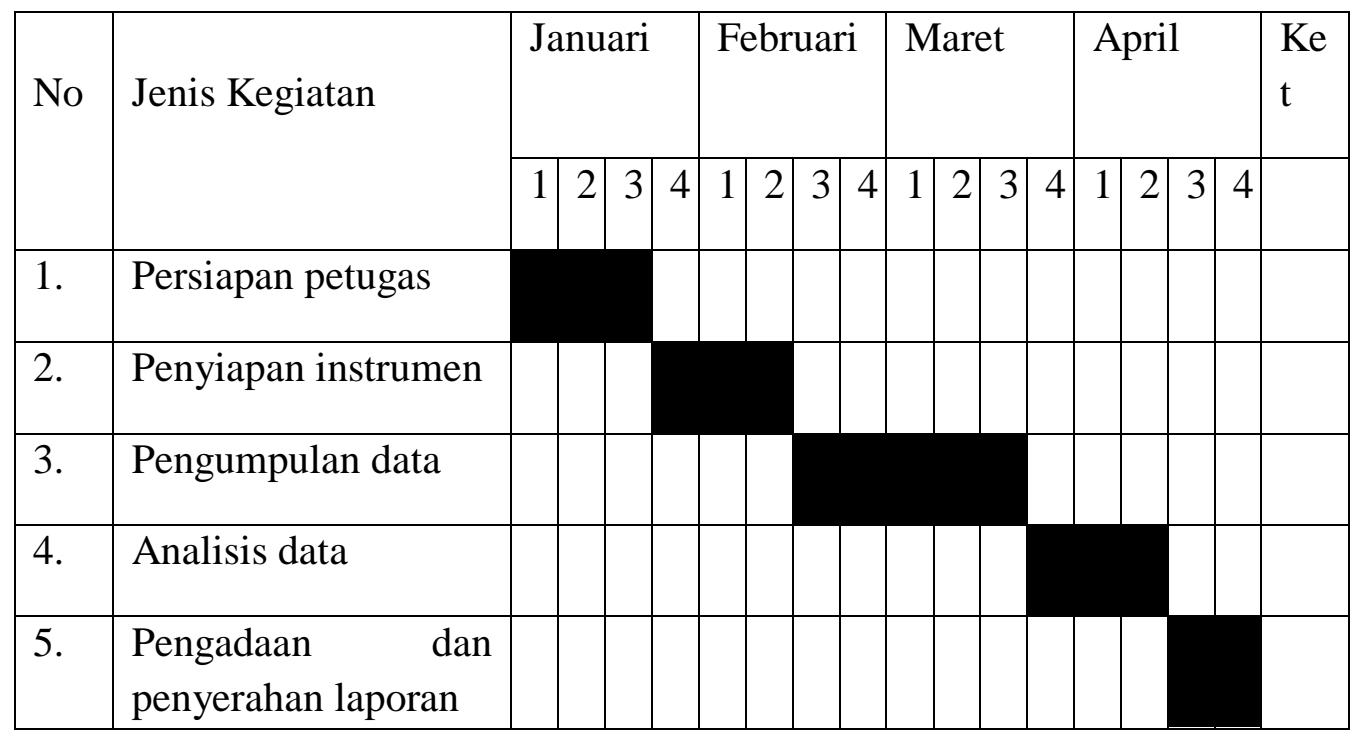

Gambar Rencana Operasi Evaluasi Program Pembelajaran.

\section{Kesimpulan}

Evaluasi atau penilaian merupakan bagian penting dalam pengelolaan atau manajemen pelaksanaan bimbingan dan konseling sesuai dengan dengan perkembangan yang terjadi baik pada program sekolah secara keseluruhan, perkembangan sosial dan tantangan yang terjadi dalam pendidikan maka program layanan bimbingan dan konseling tidak boleh statis atau itu ke itu. Demikian pula dilihat dari perkembangan program itu sendiri, suatu program layanan bimbingan dan konseling perlu dikembangkan dan diperbaiki sehingga dapat dirancang dan direalisasikan sesuai dengan perkembangan kebutuhan peserta didik sebagai salah satu sasaran layanan. Sekalipun layanan evaluasi bukan merupakan layanan yang langsung kepada siswa, namun pelaksanaan evaluasi akan memberikan dampak terhadap peningkatan layanan yang dibutuhkan oleh siswa. Sehingga pada akhirnya siswa dapat merasakan dampak peningkatan atau perubahan yang sesuai dengan dinamika pada aspek yang dikembangkan dalam suatu program.

Model evaluasi muncul karena adanya usaha eksplanasi secara kontinu yang diturunkan dari perkembangan pengukuran dan keinginan manusia untuk 
Model dan Rancangan Evaluasi Program... (Siti Wahyuni Siregar) 289 berusaha menerapkan prinsip-prinsip evaluasi pada cakupan yang lebih komprehensif termasuk pada bidang ilmu pendidikan, perilaku dan seni.

Dalam melaksanakan evaluasi program bimbingan dan konseling ada beberapa model yang dapat digunakan, diantaranya adalah model evaluasi goal attainment yang dikembangkan oleh Tyler, model evaluasi formative dan summative yang dikembangkan oleh Michael Scriven, model evaluasi responsif yang dikembangkan Stake, serta model evaluasi CIPP (context, input, process and product) oleh Daniel Sufflebeam dan kawan-kawan. 


\section{Daftar Referensi}

Aip Badrujaman, Teori dan Aplikasi Evaluasi Program Bimbingan Konseling, Jakarta: Indeks, 2011.

Kementrian Pendidikan dan Kebudayaan Direktorat Jenderal Pendidikan Menengah Direktorat Pembinaan PTK Dikmen, Materi Bimbingan Teknis Pengembangan Karir Guru BK Dikmen, 2012.

Mamat Supriatna, Bimbingan dan Konseling Berbasis Kompetensi; Orientasi Dasar Pengembangan Profesi Konselor, Jakarta: Rajawali Press, 2011.

S. Eko Puto Widoyoko, Evaluasi Program Pembelajaran; Panduan Praktis Bagi Pendidik dan Calon Pendidik, Yogyakarta: Pustaka Pelajar, 2009.

Suharsimi Arikunto, Cepi Safruddin AJ, Evaluasi Program Pembelajaran, Jakarta: Bumi Aksara, 2007.

Sukardi, Evaluasi Pendidikan; Prinsif \& Operasional, Jakarta: Bumi Aksara, 2008.

Wirawan, Evaluasi; Teori, model, Standar, Aplikasi dan Profesi, (Jakarta: Rajawali Press, 2011 